\title{
Rheological and Microbiological Characteristics of Hops and Hot Trub Particles Formed during Beer Production
}

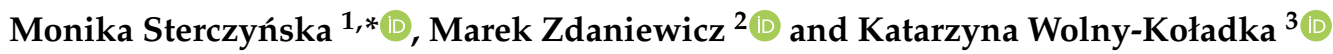 \\ 1 Faculty of Mechanical Engineering, Department of Food Industry Processes and Facilities, \\ Koszalin University of Technology, 15-17 Raclawicka, PL75620 Koszalin, Poland \\ 2 Department of Fermentation Technology and Microbiology, University of Agriculture in Krakow, \\ Balicka 122, 30-149 Krakow, Poland; marek.zdaniewicz@urk.edu.pl \\ 3 Department of Microbiology and Biomonitoring, University of Agriculture in Krakow, \\ Mickiewicza Ave 24/28, 30-059 Krakow, Poland; katarzyna.wolny@urk.edu.pl \\ * Correspondence: monika.sterczynska@tu.koszalin.pl
}

Citation: Sterczyńska, M.; Zdaniewicz, M.; Wolny-Koładka, K. Rheological and Microbiological Characteristics of Hops and Hot Trub Particles Formed during Beer Production. Molecules 2021, 26, 681. https://doi.org/10.3390/molecules 26030681

Academic Editors: Assunta Marrocchi and Ombretta Marcon

Received: 8 December 2020

Accepted: 26 January 2021

Published: 28 January 2021

Publisher's Note: MDPI stays neutral with regard to jurisdictional claims in published maps and institutional affiliations.

Copyright: () 2021 by the authors. Licensee MDPI, Basel, Switzerland. This article is an open access article distributed under the terms and conditions of the Creative Commons Attribution (CC BY) license (https:// creativecommons.org/licenses/by/ $4.0 /)$.

\begin{abstract}
During the production of beer, and especially beer wort, the main wastes are spent grain and hot trub, i.e., the so-called "hot break." Combined with yeast after fermentation, they represent the most valuable wastes. Hot trub is also one of the most valuable by-products. Studies on the chemical composition of these sediments and their rheological properties as waste products will contribute to their effective disposal and even further use as valuable pharmaceutical and cosmetic raw materials. So far, hot trub has been studied for morphology and particle distribution depending on the raw material composition and beer wort extract. However, there are no preliminary studies on the rheological properties of hot trub and hops. In particular, no attention has yet been paid to the dependence of these properties on the hop variety or different protein sources used. The aim of this study was to examine the effect of different hopping methods on hot trub viscosity and beer wort physicochemical parameters. Additionally, the hop solutions were measured at different temperatures. A microbiological analysis of hop sediments was also performed to determine the post-process survival of selected microorganisms in these wastes. For manufacturers of pumps used in the brewing industry, the most convenient material is that of the lowest viscosity. Low viscosity hot trub can be removed at lower velocities, which reduces costs and simplifies washing and transport. The sediments also had similar equilibrium viscosity values at high shear rates.
\end{abstract}

Keywords: hop pellets; Polish hops; hot trub; rheology; viscosity; waste; beer; microorganisms

\section{Introduction}

For many years, industrial waste generation has been increasing at an alarming rate worldwide [1]. In the food industry, including the brewing industry, there are many problems with waste management and disposal. At the same time, they generate significant costs and are an important aspect in brewery operations [2,3]. In particular, this concerns the use of new recipes for beer wort production. Beer consumption is steadily increasing and the brewing industry increases its revenues every year [4,5]. Each brewery attempts to keep waste disposal costs low, and government-imposed legislation has become more stringent over the years [3,5-8]. The brewing industry consumes significant amounts of water and thus produces large amounts of wastewater- $3.3 \mathrm{~m}^{3}$ of wastewater per $1 \mathrm{~m}^{3}$ of beer [9-11]. Furthermore, $51.2 \mathrm{~kg}$ of solid waste is produced per $1 \mathrm{~m}^{3}$ of finished beer, including hot trub. The biological oxygen demand (BOD) for hot trub is as high as about $110,000 \mathrm{mg}-\mathrm{kg}^{-1}$ [7]. CIP (Cleaning in Place) installations or other pipelines transport raw materials, semi-finished products, finished products, and manufacturing waste. The selection of suitable pumps and optimization of their parameters are determined by the medium properties, including those of a rheological nature, e.g., viscosity [12-14]. It is also important to review the material before production and use on a larger scale, 
to design optimal equipment and improve overall process economics $[15,16]$. In their study, Piepiórka-Stepuk et al. [17] focused on the regeneration of detergents in brewery production at different temperatures. The authors found that the solutions cleaned in the CIP installation in the brewery differ in the degree and type of contamination [17].

During the production of beer, and especially beer wort, the main wastes are spent grain and hot trub, i.e., the so-called "hot break" $[3,5,14,18]$. Combined with yeasts after fermentation, they represent the most valuable wastes [7]. Hot trub is also one of the most valuable by-products. Studies on the chemical composition of these sediments and their rheological properties as waste products will contribute to their effective disposal and even further use as valuable pharmaceutical and cosmetic raw materials $[3,19]$.

One of the first stages of beer production is the brewing of beer wort. After boiling, the wort is pumped into a whirlpool (the so-called "breaking"), in which the hot trub is separated [20]. Wort clarification in the whirlpool is mainly aimed at reducing the excess protein and tannic substances. Their presence adversely affects a number of processes and the commercial shelf life of the finished product. The hot trub density is higher than the beer wort density and is approx. $1.2-2.25 \mathrm{~g}-\mathrm{cm}^{-3}$ [21]. Hot trub is a mixture of insoluble, denatured proteins, complex carbohydrates, lipids, tannins, and many other minerals $[22,23]$. The share of individual components of the sediment varies depending on the raw materials used [24], and is usually as follows: proteins (40 to $70 \%$ ), bitter substances (7 to $32 \%$ ), polyphenols ( 20 to $30 \%$ ), carbohydrates (4 to $8 \%$ ), fats (1 to $8 \%$ ), ash (nearly $5 \%$ ), and bitter acids and fats (1 to $2 \%)[23,25]$. Wort with high nitrogen content loses about $6 \%$ of it due to the precipitation of hot trub during boiling [26]. So far, the sediment has been studied for morphology and particle distribution (by the Shadow Sizing method) depending on the raw material composition and beer wort extract [27]. The hot trub particle size ranges from 30 to $80 \mu \mathrm{m}$ [23] or up to $200 \mu \mathrm{m}$ [28]. Studies showed that these particles can be up to $500 \mu \mathrm{m}$ in size. Most particles are from about 30 to $140 \mu \mathrm{m}$ [27]. However, the largest estimated diameter values were around $8000 \mu \mathrm{m}$ [25]. These relationships should be further examined, especially the effect of the hop pellet type on the obtained hot trub viscosity. In addition, the hop solution rheology at different temperatures is an important aspect when using automatic dosing of raw materials nowadays.

For many years now, the rheological properties of raw materials or products have been tested in almost all aspects of the food industry [29-31] or food waste [32]. Measurements of wort viscosity provide information on the wort filtration and clarification time in the brewery. The settings of pumps for the transport of wort and waste, e.g., hot trub, also depend on the rheological properties. Many studies have already discussed the phenomenon occurring in the whirlpool and hot trub forming a cone [33-35]. However, there are no preliminary studies on the rheological properties of hot trub and hops. In particular, no attention has yet been paid to the dependence of these properties on the hop variety or various raw protein materials (e.g., barley malt) used.

The antimicrobial properties of hops contained in hop sediments and spent hops allow the use of this waste, among others, as a fertilizer or-as noted above-as a pharmaceutical and cosmetic raw material. This method seems to be more reasonable than the application for animal feed purposes, mainly due to the relatively high content of bitter compounds [8]. Fărcaş et al. [36] stated that because of the presence of 2-methyl-3-buten-2-ol, the application of hop sediment as a feed additive is not justified. Hop residue (with its high content of essential oils) may also be successfully used to produce natural, inexpensive, ecological repellents to fight pests in stored food [8,37]. Hop sediments can also be used in medicine as a sedative or in cosmetology, which results from the presence of specific organic compounds [8], as well as its antioxidant and antimicrobial effects [38]. Unfortunately, a large share of hop sediments is still treated as waste and sent to landfills [39]. Therefore, alternative options for the processing of brewing waste are increasingly being proposed, using the antimicrobial properties of hops contained in the sediments. The proposed measures include, inter alia, the possibility of composting hop sediments for later use as a fertilizer in agriculture $[40,41]$. Another proposed option for the management of 
hop sediments was studies aimed at evaluating the use of refuse-derived fuels (RDF) and undersize fraction from municipal solid waste (UFMSW) as bulking agents for co-biodrying hot trub. Therefore, the obtained results suggest using RDF as the main component in the process of hot trub co-biodrying [42]. The literature offers many examples of possible ways of managing hop sediments, which are the waste in beer production, showing the real scale of the problem. The in-depth (physico-chemical, rheological, microbiological) characteristics of this raw material is of key importance here, as it enables the creation of effective and economically justified methods of utilization.

The aims of this study are presented below:

(1) It evaluated the influence of different hopping methods on hot trub viscosity and beer wort physicochemical parameters.

(2) The rheological properties of hop solutions were measured at different temperatures.

(3) Microbiological analyses were performed to check whether the appropriate technological (cleanliness of the installation) and hygienic (high temperature) conditions were maintained at all stages of the process, preventing the growth of undesirable microorganisms.

\section{Material and Methods}

\subsection{Material}

The material used in the study was hot trub, i.e., the so-called "break" precipitated while hopping the beer wort made using various recipes. Additionally, recipes for beers from still other hop varieties were prepared and the precipitated sediments were evaluated for selected characteristics and physicochemical properties. Standardized methods according to the EBC (European Brewing Convention) and the most recent research equipment were used for production and physicochemical characterization [43]. Raw materials used in the study included Mep@Pilsner barley malt (malt used for top-fermenting and bottom-fermenting beers, color range: 3.5 to 4.5 EBC units), Mep@Lager (barley malt of 3-3.5 EBCs), Puławski hop variety T-90 (bitter variety from Poland, characterized by fruity-flowery flavor and spicy aroma, alpha-acids of 7.2\%), Magnat hop variety T-90 (a super-bitter variety of hops bred in Poland, alpha-acids of 14.0\%), Lubelski hop variety T-90 (a super-aromatic variety, alpha-acids of 3.0\%), and Fermentis Saflager S-23 beer yeast in dry form for bottom fermentation.

\subsection{Rheological Properties}

The tests were carried out to determine the rheological properties of hot trub and hops dissolved in water at different temperatures $\left(21^{\circ} \mathrm{C}\right.$ or $\left.100{ }^{\circ} \mathrm{C}\right)$. A Viscotester iQ rheometer, hot trub container, and water bath were used. Samples of $40 \mathrm{~g}$ each were prepared for testing. Before application, the sediment or hops were unified, all lumps were broken, and the separated wort was mixed. Wort sediments from a semi-technical scale were standardized to contain $76 \%$ water and $24 \%$ dry matter. After placing the sediment in a container, air bubbles were removed. The container was closed and stored in a refrigerator for relaxation. Then, each time after more than $12 \mathrm{~h}$, the test was performed. The Vane-in-acup geometry was chosen with a $3 \mathrm{~mm}$ gap, as only this geometry allowed measurements. No reagents were used for the rheological tests.

Rheological parameters were determined by the hysteresis loop test. This test allows the viscosity changes to be determined and the thixotropy to be evaluated. Thixotropy means that under the conditions of isothermal flow of the liquid previously at rest for a longer time at a constant shear rate, the tangential stress decreases reversibly with time. Thixotropy is defined as any process in which, due to the destruction of the internal structure of a system, the internal friction of a liquid decreases isothermally with the passage of shear time, as well as a time-measurable slow return to its original consistency at rest.

Measurements of hop solution were carried out at three temperatures: $15^{\circ} \mathrm{C}, 60^{\circ} \mathrm{C}$, and $80^{\circ} \mathrm{C}$. On the other hand, measurements of the hot trub viscosity were carried out 
at $20,40,60$, and $80^{\circ} \mathrm{C}$. Both tests were conducted under controlled rate of rotation (CR) conditions, with the following settings: increasing shear rate- $\dot{\gamma} 01 / \mathrm{s}-501$ /s linearly for a time of $100.00 \mathrm{~s}$ and decreasing shear rate- $\dot{\gamma} 501 / \mathrm{s}-01 / \mathrm{s}$ linearly for a time of $100.00 \mathrm{~s}$.

Rheological measurements were taken with a Thermo Scientific HAAKE Viscotester $\mathrm{iQ}$ rotational rheometer with a Peltier system for temperature control. The sediment was examined in a vane cup configuration. The sediment was heated in a water bath to the desired temperature. Wort and mash were studied in a co-axial cylinder system with a double gap. Measurements of wort and mash viscosity were carried out at a shear rate of $\dot{\gamma}$ $10001 / \mathrm{s}$ for a temperature changing linearly from $0{ }^{\circ} \mathrm{C}$ to $80^{\circ} \mathrm{C}$ with $0.2^{\circ} \mathrm{C} / \mathrm{s}$ for $300 \mathrm{~s}$.

\subsection{Dry Matter Content}

In order to determine the dry matter content, it was necessary to dry the hot trub. An electronic scale, a scaling container, and a moisture analyzer were used. A total of $3 \mathrm{~g}$ of samples of hot trub, hops, and yeast were taken and transferred to the scaling container, which was then placed in the moisture analyzer. After drying, the percentage of moisture was recorded and the dry matter content was calculated.

\subsection{Total Protein Content}

Protein was determined by the Kjeldahl method, which was carried out in 3 stages, including sample mineralization, distillation, and titration. This test involved the determination of nitrogen compounds in the protein. Reagents used in the test included $4 \%$ boric acid $\left(\mathrm{H}_{3} \mathrm{BO}_{3}\right)$, concentrated sulfuric acid, $0.1 \mathrm{M}$ hydrochloric acid $(\mathrm{HCl})$, 33\% sodium hydroxide $(\mathrm{NaOH})$, a catalyst, and distilled water. A $3.0 \mathrm{~g}$ sample of hot trub was weighed on the electronic scale and transferred to the distillation flask. A catalyst and $10 \mathrm{~mL}$ of sulfuric acid were then added and placed in the digestion flask. After mineralization, the sample (dark brown color) was allowed to cool. After cooling, $20 \mathrm{~mL}$ of distilled water with phenolphthalein was added to the distillation flask and placed in the distillation apparatus. Boric acid $(40 \mathrm{~mL})$ and 4 drops of Tashiro indicator were measured into the $250 \mathrm{~mL}$ flask. After distillation, the $0.1 \mathrm{M} \mathrm{HCl}$ sample was titrated until the color changed.

On the basis of the titration results obtained, the amount of nitrogen in the tested material was calculated as follows:

$$
d=((a-b) \cdot n \cdot 14) /(1000 \cdot m) \cdot 100
$$

where

a-volume of solution used for titration;

$\mathrm{b}$-volume of solution used for blank test;

$\mathrm{n}$-molarity;

$\mathrm{m}$-weight of sample; and

14-amount of nitrogen, constant.

The nitrogen results obtained were converted to protein by multiplying them by a conversion factor of 6.25 for all results.

\subsection{Extract}

Extract of the obtained cold wort (beer wort) was analyzed with a Hanna Instruments refractometer of the HI 96801 type. The measurement was read in Plato degrees. Deionized water was used for calibration.

\subsection{Microbiological Analysis of Hot Trub}

The samples of hot trub were collected in sterile containers on the same dates as the material for other analyses. The samples were subjected to microbiological analysis using the serial dilution method by Koch. Microbiological analyzes, performed in triplicate, included the assessment of the number of selected groups of microorganisms, i.e., vegetative and endospore bacteria (TSA, BTL Poland, grown at $37^{\circ} \mathrm{C}$ for $24 \mathrm{~h}$ ), mold fungi (MEA, BTL 
Poland, grown at $24^{\circ} \mathrm{C}$ for 5 days), and actinomycetes (Pochon's agar, BTL Poland, grown at $28^{\circ} \mathrm{C}$ for 7 days). The number of vegetative bacteria and spores testifies to the abundance of nutrients easily available for the microorganisms in raw materials. A plurality of bacteria, fungi, and actinomycetes also indicates favorable conditions (temperature, substrate $\mathrm{pH}$, humidity) for the growth and development of microorganisms. Potentially pathogenic bacteria were also determined: Staphylococcus spp. (MSA agar, BTL Poland, grown at $37^{\circ} \mathrm{C}$ for $24 \mathrm{~h}$ ), Escherichia coli (TBX agar, BTL Poland, grown at $44{ }^{\circ} \mathrm{C}$ for $24 \mathrm{~h}$ ), Salmonella spp. and Shigella spp. (SS agar, BTL Poland, grown at $37^{\circ} \mathrm{C}$ for $24 \mathrm{~h}$ ), Enterococcus faecalis (SB agar, BTL Poland, grown at $37^{\circ} \mathrm{C}$ for $48 \mathrm{~h}$ ), Pseudomonas aeruginosa (CN agar, BTL Poland, grown at $37^{\circ} \mathrm{C}$ for $48 \mathrm{~h}$ ), Proteus spp. (Nogrady agar, BTL Poland, grown at $37^{\circ} \mathrm{C}$ for $48 \mathrm{~h}$ ), and Clostridium perfringens (SC agar, BTL Poland, grown at $37^{\circ} \mathrm{C}$ for $24 \mathrm{~h}$ ), whose presence may pose a threat from an epidemiological point of view and is an important signal informing about microbial contamination [44]. After the incubation period, the grown colonies were counted and the results reported in colony forming units per gram of dry matter of the sample (CFU.g $\left.{ }^{-1} \mathrm{~d} . \mathrm{m}.\right)$.

\subsection{Statistical Analysis}

Each variant of the experiment was carried out in 5 repetitions. The obtained results were grouped and their mean values and standard deviation were determined. The obtained values were compared and subjected to statistical interpretation. The significance of the effect of the examined variables on protein, dry matter, and extract of beer worts, hops, and hot trub was determined by single-factor and two-factor ANOVA analysis. The significance of differences between means was verified by Duncan's test $(p<0.05)$. Statistical analysis was performed using the Statistica 13 software from StatSoft.

\subsection{Experiment Description}

Beer wort and hot trub precipitated from it were produced in the laboratory with the use of a Speidel-Breumeister mashing and brewing boiler on a semi-technical scale. Clarified wort and a sample after secondary fermentation was obtained from the industrial brewery. After preliminary tests, the brewing process resulted in the production of 100\% Mep@Pilsner malt and 100\% Mep@Lager malt with Puławski hops, which was characterized by the highest amount of protein and dry matter.

In order to obtain optimal conditions for enzymes, the mashing of each wort was carried out with guidelines similar to those for the production of congress wort.

The temperature range included $45-50{ }^{\circ} \mathrm{C}$-for proteolytic enzymes and $\beta$-glucanases, $62-65{ }^{\circ} \mathrm{C}$ - the optimal temperature for $\beta$-amylase activity, $70-75^{\circ} \mathrm{C}$ - the optimal temperature for $\alpha$-amylase activity, and $78{ }^{\circ} \mathrm{C}$-the temperature of the mashing end (mash-off) and mash lautering. Each time, iodine tests were carried out in order to check the quality of the mashing process (mashing saccharification). Determining the saccharification rate is very important. An iodine test is the most commonly used method for determining the saccharification of mash. The mash is considered to be saccharged when there is no longer any change in its color after the addition of iodine solution. Ten min after beginning the mash a drop of mash is transferred to the porcelain spot plate and a drop of iodine solution is added. The test is repeated at 5 min intervals until saccharification is complete and a clear yellow area is obtained. The result is reported as "less than $10 \mathrm{~min}$," "10 to $15 \mathrm{~min}$," etc. If saccharification is incomplete after one hour this must be stated.

The raw material input of individual variants of worts from which precipitated hot trub was examined was 6 kg of ground barley malt (Mep@Pilsner malt or Mep@Lager), $60 \mathrm{~g}$ of hops, and $33 \mathrm{~L}$ of water (of which $5 \mathrm{~L}$ were used for sweetening).

The experimental variants were different boiling times (60 or $30 \mathrm{~min}$ ), wet hopping, and the addition of hops (dry hopping) to the brewery wort (made from 100\% Mep@Pilsner malt) sample after secondary fermentation.

Adding hops after boiling and cooling the wort was intended to increase the level of hoppy aroma in the beer without increasing the bitterness. This treatment is more 
often used in the production of top-fermented beers. A slightly different late hopping technique is used for bottom-fermenting beers. Very often hops are used during secondary fermentation or lagering.

Additionally, an experiment was carried out to evaluate the reaction of the hop pellets to the dissolution of the material in water at different temperatures $\left(21^{\circ} \mathrm{C}\right.$ and above $\left.100{ }^{\circ} \mathrm{C}\right)$.

The sample identification system used is presented in Table 1.

Table 1. List of analyzed variants.

\begin{tabular}{ll}
\hline Variant Symbol & \multicolumn{1}{c}{ Symbol Designation } \\
\hline O_Przem_P & Hot trub from the industrial brewery \\
O_P_60 & Hot trub precipitated from Pilsner malt wort and boiled for $60 \mathrm{~min}$ \\
O_L_60 & Hot trub precipitated from Lager malt wort and boiled for $60 \mathrm{~min}$ \\
O_D_60 & Hot trub with yeast precipitated from Pilsner malt wort and boiled for $60 \mathrm{~min}$ \\
O_P_30 & Hot trub with yeast precipitated from Pilsner malt wort and boiled for $30 \mathrm{~min}$ \\
O_L_30 & Hot trub precipitated from Lager malt wort and boiled for 30 min \\
Ch_z & Puławski hop pellets dissolved in water at $21^{\circ} \mathrm{C}$ \\
Ch_g & Puławski hop pellets dissolved in water at $100^{\circ} \mathrm{C}$ \\
D & Freeze-dried yeast \\
Ch_Pt & Puławski hop pellets \\
Ch_M & Magnat hop pellets \\
Ch_L & Lubelski hop pellets \\
B_Przem & Industrial wort \\
B_P & Pilsner malt wort \\
B_L & Lager malt wort \\
O_1 & Hot trub precipitated from Pilsner malt wort and boiled 60 min \\
O_2 & Hot trub precipitated from Lager malt wort and boiled for 60 min \\
O_3 & Hot trub with yeast precipitated from Pilsner malt wort and boiled for $60 \mathrm{~min}$ \\
O_4 & Hot trub precipitated from Pilsner malt wort and boiled for $30 \mathrm{~min}$ \\
O_5 & Hot trub precipitated from Lager malt wort and boiled for $30 \mathrm{~min}$ \\
Zw & Hops dissolved in water at $21^{\circ} \mathrm{C}$ \\
Gw & Hops dissolved in water at $100{ }^{\circ} \mathrm{C}$ \\
\hline
\end{tabular}

\section{Results and Discussion}

The following subsections present and discuss the results of the conducted analyses of hot trub in different experimental variants. The study does not include a section on the results of microbiological analyses, because no microbiological contaminants were determined in the studied hop sediments, which proves their full sterility and lack of microbial survival. Due to its properties (low $\mathrm{pH}$, alcohol content, anaerobic conditions, and aseptic effect of the bitter substances contained in the hops, as well as the low content of nutrients consumed by the yeast in fermentation), beer largely defends itself against the development of microbial infections $[45,46]$. Moreover, in most cases, the activity of microorganisms in the brewing industry is desirable (beer is the result of the fermentation conducted by them). On the other hand, harmful microflora can also be encountered in beer, which can not only survive, but also multiply in it and release its metabolic by-products into beer, thus causing beer spoilage, which manifests itself in sensory changes (unwanted changes in taste and smell) $[45,47]$. That is why this study assessed the occurrence of selected microorganisms with the potential to form infections and survive in unfavorable environmental conditions thanks to, inter alia, the ability to create spores, shells, and chlamidospores.

\subsection{Dry Matter}

Figure 1 shows the dry matter content in precipitated sediments and selected raw materials. The lowest percentage of dry matter was determined in hop pellets immersed in water at $21{ }^{\circ} \mathrm{C}(3.37 \%)$ compared to hops (Ch_g) with water above $100{ }^{\circ} \mathrm{C}(6.31 \%)$. The dry matter values were similar for variants with hop pellets $\mathrm{Ch} \_\mathrm{g}$, with precipitated sediments after 30 min of boiling, and after dry hopping. These values ranged from 6 to $7.7 \%$. The other sediment variants had a dry matter content twice as high. For sediments after $60 \mathrm{~min}$ 
of boiling, the highest value $(23.52 \%)$ of the examined parameter was obtained in the variant with Puławski hops boiled from wort with Pilsner malt; this value was similar to that obtained for beer yeast. The highest dry matter contents were recorded in hop pellets. Among them, the variant obtained from Puławski hops had the lowest moisture content (d.m. 92.32\%). The results were similar for the other two variants.

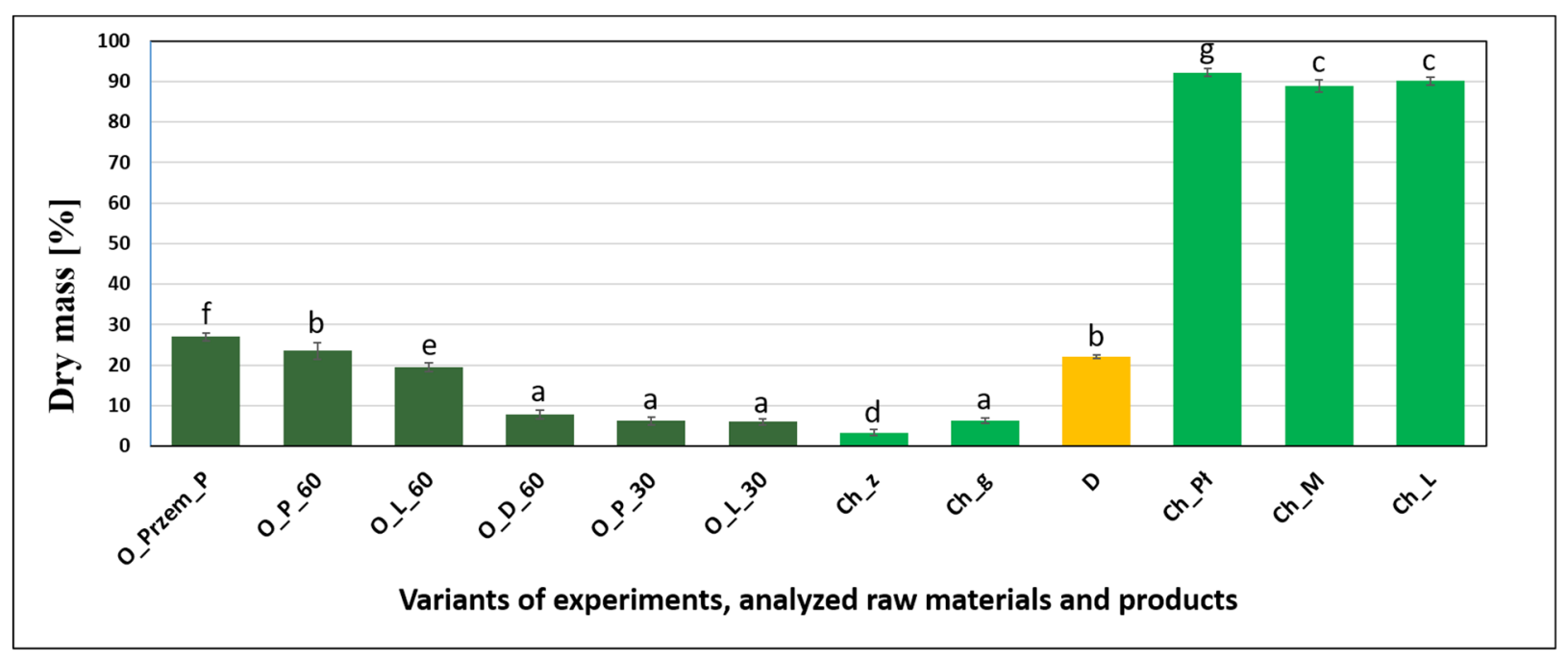

Figure 1. Dry matter of precipitated hot trub, yeast, and raw materials ( $n=5, \alpha=0.05$; homogeneous groups of results within a given parameter are marked with letters).

\subsection{Protein}

Hot trub separation can be achieved by sedimentation, centrifugation, or filtration of the beer wort. The most effective precipitation is for hopped wort. Malting barley contains as much as $92 \%$ of nitrogen compounds in the form of proteins, mainly glutelins, i.e., simple proteins. They do not pass into the solution because they remain almost whole in the spent grain. Other protein compounds are prolamines (insoluble in water, soluble in alcohol), largely remaining in the spent grain, and globulins, also called "edestins," (soluble in diluted salt solutions and in mash, heat coagulating, do not precipitate completely). The smallest proportion of barley is made up of albumin (only $11 \%$ of proteins), which precipitates completely when boiled. It is worth noting that during malting and mashing, the content decreases. During wort boiling, when the sediment is precipitated, the hop oil components are dissolved and transformed. They are responsible for the formation of the characteristic hoppy smell and taste in beer. These transformations depend on the wort chemical composition and $\mathrm{pH}[20,48]$.

Figure 2 shows a chart of the total content of protein from precipitated sediments and selected raw materials.

The lowest total protein content was determined for hop pellets immersed in water at different temperatures and in sediments precipitated during $30 \mathrm{~min}$ of boiling, regardless of beer wort variants. These values oscillated between 3.02 and 3.82\%. Among hot trub, the highest protein content was observed for industrial sediment. In the case of variants produced in the laboratory, the highest protein content was found in the sediment with Pilsner malt precipitated after $60 \mathrm{~min}$ of boiling $(7.98 \%)$. The protein values in beer worts and in the sediments were similar depending on the experimental variant. In the case of hot trub after $60 \mathrm{~min}$ of boiling, the highest parameter value was obtained in the variant with Puławski hops (23.52\%) and it was similar to the mass obtained from beer yeast. The highest protein values were recorded in hop pellets. Among them, the variant with Puławski hops had the highest protein content (19.34\%). On the other hand, among the hop pellets in general, the lowest protein content was recorded in Lubelski hops (12.31\%). 


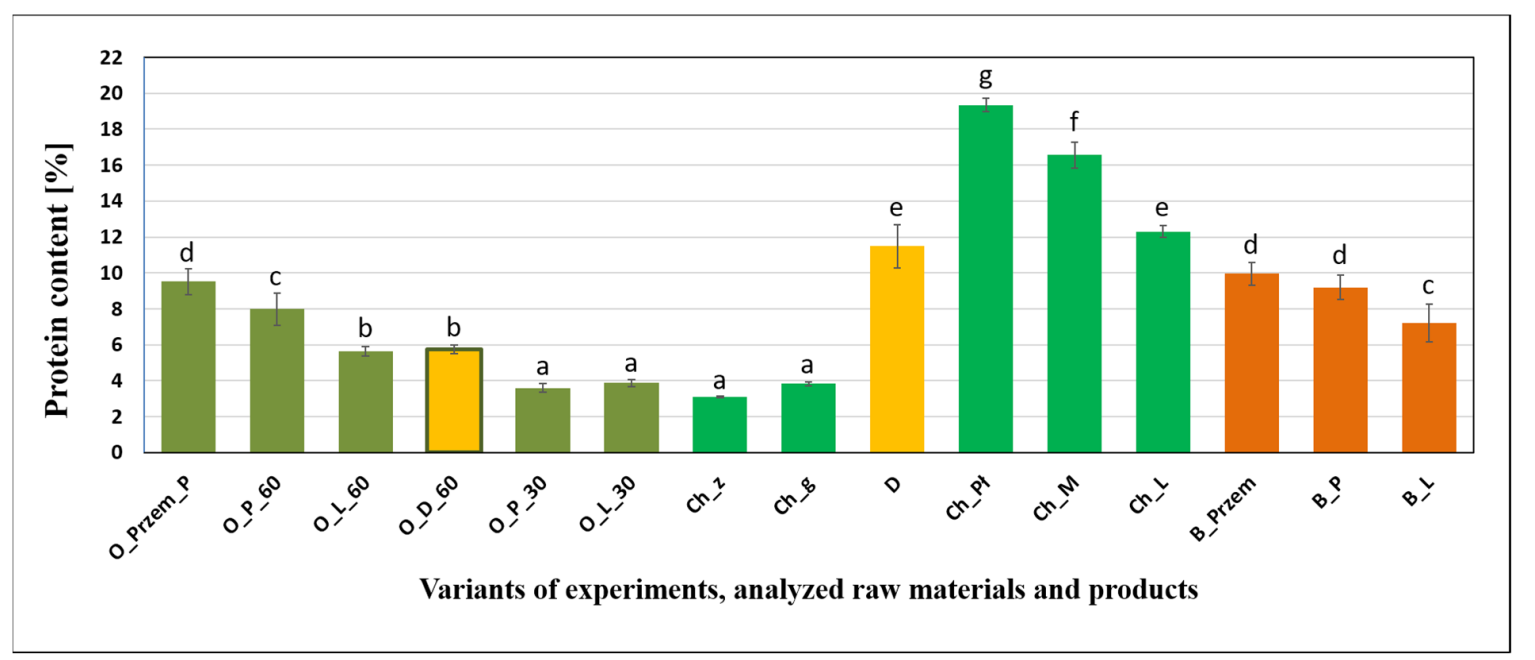

Figure 2. Protein content in beer wort, hot trub, yeast, and raw materials ( $n=5, \alpha=0.05$; homogeneous groups of results within a given parameter are marked with letters).

\subsection{Extract Content}

The beer wort extract concentration is one of the most important quality parameters and can indicate the brewery's efficiency $[49,50]$. It is directly related to the amount of fermenting sugars and is therefore very important for the fermentation process [49]. Figure 3 shows a chart of the extract of worts produced with $100 \%$ Pilsner malt and Puławski hops after $60 \mathrm{~min}$ of boiling.

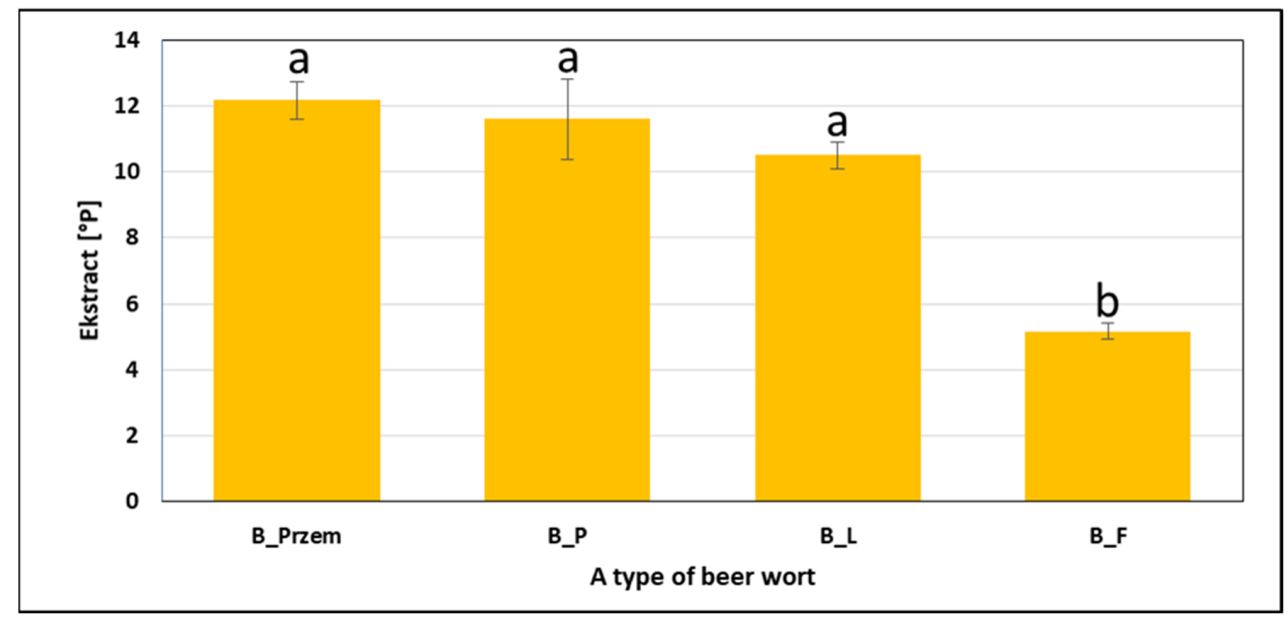

Figure 3. Beer wort extract $(n=5, \alpha=0.05$; homogeneous groups of results within a given parameter are indicated with letters).

There were no statistically significant differences in the results obtained for beer wort extract produced with $100 \%$ Pilsner malt and Puławski hops after 60 min of boiling, as it ranged from 10.71 to $12.5^{\circ} \mathrm{P}$. On the other hand, a much lower value of the examined parameter was obtained for wort after dry hopping $\left(5.2^{\circ} \mathrm{P}\right)$. Many authors argued that the distribution of hot trub particles depended on the extract [27], whereas it did not have a major impact on the rheological properties. This variable did not introduce additional differentiation and was the same for all variants without yeast.

\subsection{Viscosity and Thixotropy}

The measurements made with the rheometer determine the relationship between the values of tangent stress $\tau$ and shear rate $\dot{\gamma}$. The flow curve shows the relation between stresses as a function of $\tau=f(\dot{\gamma})$. For a Newtonian fluid, this is a straight line passing through 
the beginning of the coordinate system. Any other curve describes a non-Newtonian fluid [51,52]. A viscosity curve can also be plotted, which represents the dependence of viscosity $\eta$ on shear rate as a function of $\eta=f(\dot{\gamma})$. The two curves are equivalent. In rheometric measurements, a flow curve is first obtained, which can be converted to a viscosity curve. A chart of the viscosity changes in the form of a hysteresis loop for hot trub from different wort variants is shown in Figure 4.
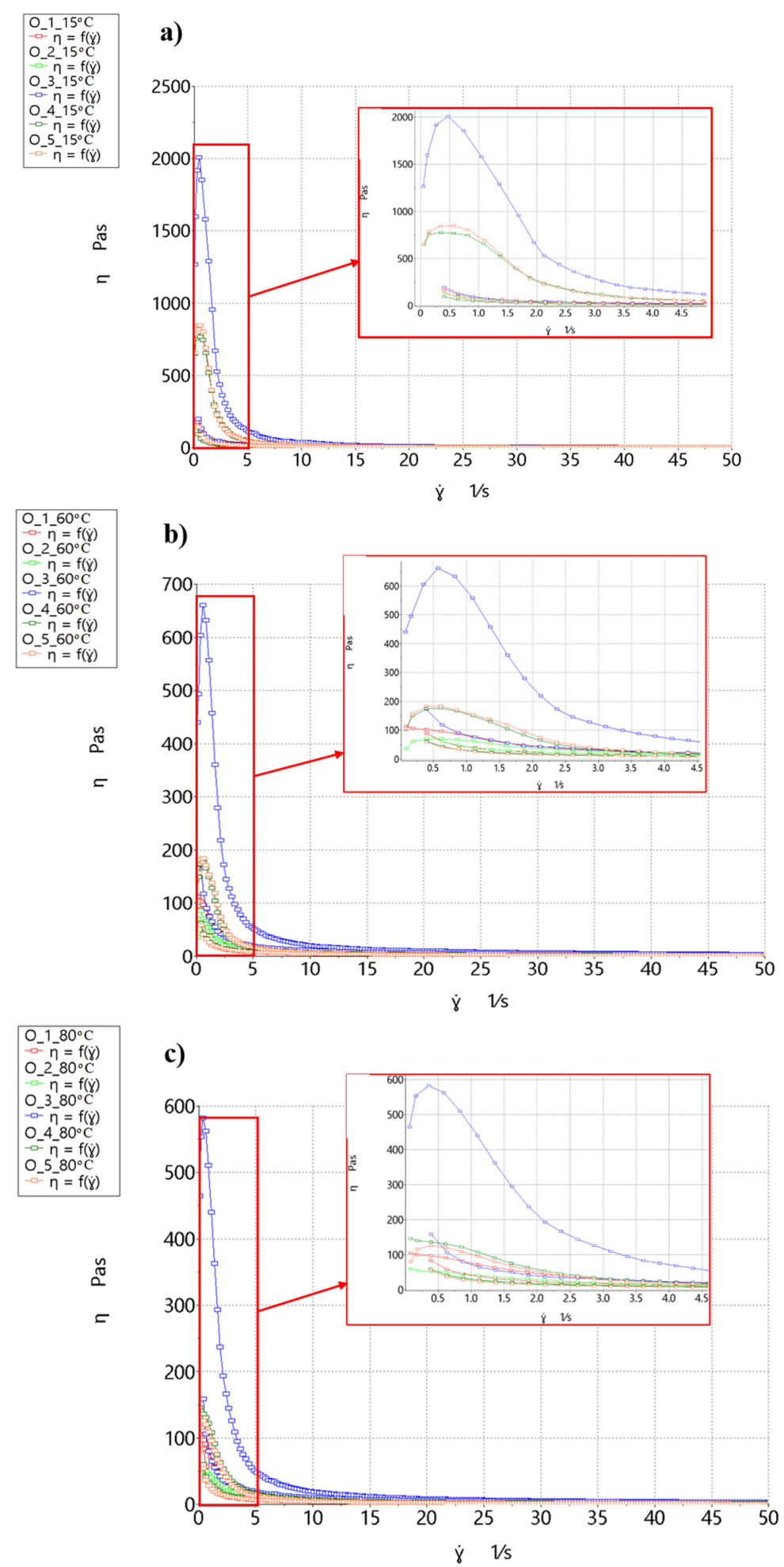

Figure 4. Viscosity in the form of a thixotropy loop of hot trub depending on the temperature: (a) $15^{\circ} \mathrm{C}$, (b) $60^{\circ} \mathrm{C}$, and (c) $80^{\circ} \mathrm{C}$. 
Hot trub is a non-Newtonian fluid with two characteristic points-maximum viscosity and equilibrium viscosity. Maximum viscosity can be related to yield point: As the maximum value is exceeded, hot trub begins to flow. In turn, equilibrium viscosity is reached as shear rate tends to infinity. The highest maximum viscosity $\left(\eta_{\max }\right)$ value at all temperatures was obtained in the sediment precipitated from Pilsner malt wort, mixed with yeast, and boiled for $60 \mathrm{~min}\left(\mathbf{O} \_3\right)$. At $15{ }^{\circ} \mathrm{C}$, the $\eta_{\max }$ was $2008.3 \mathrm{~Pa} \cdot \mathrm{s}$; at $60{ }^{\circ} \mathrm{C}$, the value decreased to $660.9 \mathrm{~Pa} \cdot \mathrm{s}$; and at $80^{\circ} \mathrm{C}$, it was $464.9 \mathrm{~Pa} \cdot \mathrm{s}$.

The lowest maximum viscosity characterized hot trub precipitated from Pilsner malt worts and boiled for $60 \mathrm{~min}\left(\mathbf{O} \_2\right)$. For this sediment, the maximum viscosity value at $15^{\circ} \mathrm{C}$ was $588.1 \mathrm{~Pa} \cdot \mathrm{s}$; at $60{ }^{\circ} \mathrm{C}, \eta_{\max }$ decreased to $70.7 \mathrm{~Pa} \cdot \mathrm{s}$; and at $80{ }^{\circ} \mathrm{C}$, $\eta_{\max }$ was $59.5 \mathrm{~Pa} \cdot \mathrm{s}$.

The sediment precipitated from Lager malt wort boiled for 30 min (O_5) had the second highest maximum viscosity value. For this hot trub at $15^{\circ} \mathrm{C}$, the maximum viscosity value was $847.2 \mathrm{~Pa} \cdot \mathrm{s}$; at $60^{\circ} \mathrm{C}, \eta_{\max }$ decreased to $183.9 \mathrm{~Pa} \cdot \mathrm{s}$. At $80^{\circ} \mathrm{C}, \eta_{\max }$ decreased to $126.4 \mathrm{~Pa} \cdot \mathrm{s}$.

The sediment from Pilsner malt wort boiled for $30 \mathrm{~min}$ had the third highest value of $\eta_{\operatorname{ma}} x$. The exception was the temperature of $80^{\circ} \mathrm{C}$, at which the $\mathrm{O} \_4$ sample had a higher viscosity than the $\mathbf{O} \_5$ sample. For the $\mathbf{O} \_4$ sediment at $15{ }^{\circ} \mathrm{C}$, the maximum viscosity was $773.7 \mathrm{~Pa} \cdot \mathrm{s}$; at $60{ }^{\circ} \mathrm{C}, \eta_{\max }$ decreased to $176.4 \mathrm{~Pa} \cdot \mathrm{s}$. At $80{ }^{\circ} \mathrm{C}, \eta_{\max }$ decreased to $145.2 \mathrm{~Pa} \cdot \mathrm{s}$. The O_1 sediment was precipitated from Pilsner malt worts and boiled for 60 min. For this hot trub at $15^{\circ} \mathrm{C}$, the maximum viscosity was $616.3 \mathrm{~Pa} \cdot \mathrm{s}$; at $60{ }^{\circ} \mathrm{C}, \eta_{\max }$ was $112.2 \mathrm{~Pa} \cdot \mathrm{s}$. At $80^{\circ} \mathrm{C}, \eta_{\max }$ decreased to $104.7 \mathrm{~Pa} \cdot \mathrm{s}$. In all analyzed sediment variants, the $\eta_{\max }$ value decreased as the temperature increased. The highest temperature drop was observed for the O_2 hot trub, whose viscosity decreased by $90 \%$. On the other hand, the O_3 hot trub viscosity decreased by $76 \%$. In other sediments, $\eta_{\max }$ decreased at $80{ }^{\circ} \mathrm{C}$ compared to $15{ }^{\circ} \mathrm{C}$ by nearly $82 \%$. The addition of yeast to hot trub noticeably thickened the sample. Boiling for $30 \mathrm{~min}$ gave hot trub a higher maximum viscosity than boiling for $60 \mathrm{~min}$. A similar effect was observed for the sediment precipitated form Pilsner malt compared to Lager malt.

As the shear rate increased, the sediments became thinner. At the shear rate of $\dot{\gamma}=50 \mathrm{~s}^{-1}$, the sediment reached the so-called "equilibrium viscosity" $\eta_{\text {eq. The order of }}$ and the tendency for value changes with the increase in temperature were the same as for maximum viscosity. Here, also at $80^{\circ} \mathrm{C}$, the O_4 sediment had higher viscosity than O_5, in contrast to 15 and $60{ }^{\circ} \mathrm{C}$.

The $\eta_{\text {eq }}$ values at

- $\quad 15{ }^{\circ} \mathrm{C}$ were 4.70 Pa.s (O_5), $3.38 \mathrm{~Pa} \cdot \mathrm{s}($ O_4), $3.25 \mathrm{~Pa} \cdot \mathrm{s}($ O_1), $2.59 \mathrm{~Pa} \cdot \mathrm{s}($ O_3 ), and $2.26 \mathrm{~Pa} \cdot \mathrm{s}\left(\mathrm{O} \_2\right)$;

- $60{ }^{\circ} \mathrm{C}$ were 4.26 Pa.s (O_5), $3.04 \mathrm{~Pa} \cdot \mathrm{s}\left(\mathbf{O} \_4\right), 2.82 \mathrm{~Pa} \cdot \mathrm{s}($ O_1), $2.15 \mathrm{~Pa} \cdot \mathrm{s}$ (O_2), and $2.05 \mathrm{~Pa} \cdot \mathrm{s}\left(\mathbf{O} \_3\right)$; and

- $\quad 80{ }^{\circ} \mathrm{C}$ were $3.83 \mathrm{~Pa} \cdot \mathrm{s}\left(\right.$ O_3), $1.49 \mathrm{~Pa} \cdot \mathrm{s}\left(\mathbf{O} \_5\right), 1.75 \mathrm{~Pa} \cdot \mathrm{s}\left(\mathbf{O} \_4\right), 1.23 \mathrm{~Pa} \cdot \mathrm{s}($ O_1), and $1.19 \mathrm{~Pa} \cdot \mathrm{s}($ O_2).

A comparison of the $\eta_{\max }$ and $\eta_{\text {eq }}$ values shows that the wort boiling time and the malt type affected the maximum viscosity value. With shorter boiling times, the Lager malt trub had a higher viscosity, whereas with longer boiling times, the opposite applied. Mixing the sediment with yeast resulted in a more than three-fold increase in the maximum viscosity at $15^{\circ} \mathrm{C}$, an almost six-fold increase at $60^{\circ} \mathrm{C}$, and a four-fold increase at $80{ }^{\circ} \mathrm{C}$. No significant increase was noted for equilibrium viscosity.

The sediments had substantial thixotropy, which made them sensitive to the deformation time. From the hysteresis test, the $\Delta \mathrm{A}$ parameter was obtained, i.e., the area between the rising and falling curve. The tendency for changes in the $\Delta \mathrm{A}$ value was the same as for the viscosity value. The highest values were obtained at $15^{\circ} \mathrm{C}$ and the lowest at $80{ }^{\circ} \mathrm{C}$. The highest hysteresis loop area values were observed for the $\mathrm{O} \_3$ sediment: At $15{ }^{\circ} \mathrm{C}, \Delta \mathrm{A}$ was $9171 \mathrm{~Pa} / \mathrm{s}$; at $60^{\circ} \mathrm{C}$, it was $4242 \mathrm{~Pa} / \mathrm{s}$; and at $80^{\circ} \mathrm{C}$, the parameter value was $3287 \mathrm{~Pa} / \mathrm{s}$. For O_5, $\Delta \mathrm{A}$ was $3721 \mathrm{~Pa} / \mathrm{s}$ at $15^{\circ} \mathrm{C}, 1076 \mathrm{~Pa} / \mathrm{s}$ at $60^{\circ} \mathrm{C}$, and $729.3 \mathrm{~Pa} / \mathrm{s}$ at $80^{\circ} \mathrm{C}$. For the O_4 sediment, $\Delta \mathrm{A}$ was $3521 \mathrm{~Pa} / \mathrm{s}$ at $15{ }^{\circ} \mathrm{C}, 1016 \mathrm{~Pa} / \mathrm{s}$ at $60{ }^{\circ} \mathrm{C}$, and $789.3 \mathrm{~Pa} / \mathrm{s}$ at $80{ }^{\circ} \mathrm{C}$. 


$100-20^{\circ} \mathrm{C}$
$-\square \eta=f(\dot{\gamma})$
$100-40^{\circ} \mathrm{C}$
$-\square=f(\dot{\gamma})$
$100-60^{\circ} \mathrm{C}$
$-\square \bar{\eta}=\mathrm{f}(\dot{\gamma})$
$100-80^{\circ} \mathrm{C}$
$-\square=f(\dot{\gamma})$

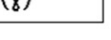

The penultimate was the $\mathbf{O} \_2$ sediment, for which $\Delta \mathrm{A}$ was $879.5 \mathrm{~Pa} / \mathrm{s}$ at $15^{\circ} \mathrm{C}, 534.6 \mathrm{~Pa} / \mathrm{s}$ at $60{ }^{\circ} \mathrm{C}$, and $562.2 \mathrm{~Pa} / \mathrm{s}$ at $80^{\circ} \mathrm{C}$. The lowest hysteresis area value was observed for the O_1 sediment, for which $\Delta \mathrm{A}$ was $105.6 \mathrm{~Pa} / \mathrm{s}$ at $15^{\circ} \mathrm{C}, 433.4 \mathrm{~Pa} / \mathrm{s}$ at $60{ }^{\circ} \mathrm{C}$, and $239.5 \mathrm{~Pa} / \mathrm{s}$ at $80^{\circ} \mathrm{C}$.

Thixotropy, like viscosity, depended on the boiling time and the malt type. The sediment was also characterized by an initial increase in viscosity at low shear rates. The addition of yeast caused a significant increase in the hysteresis loop surface area by increasing the maximum viscosity value. The return curves of all hot trubs, except O_3, were similar.

Figure 5 shows charts of viscosity changes in the form of a hysteresis loop area of the sediment precipitated from 100\% Pilsner malt boiled for $60 \mathrm{~min}$ and from wort collected from an industrial brewery.

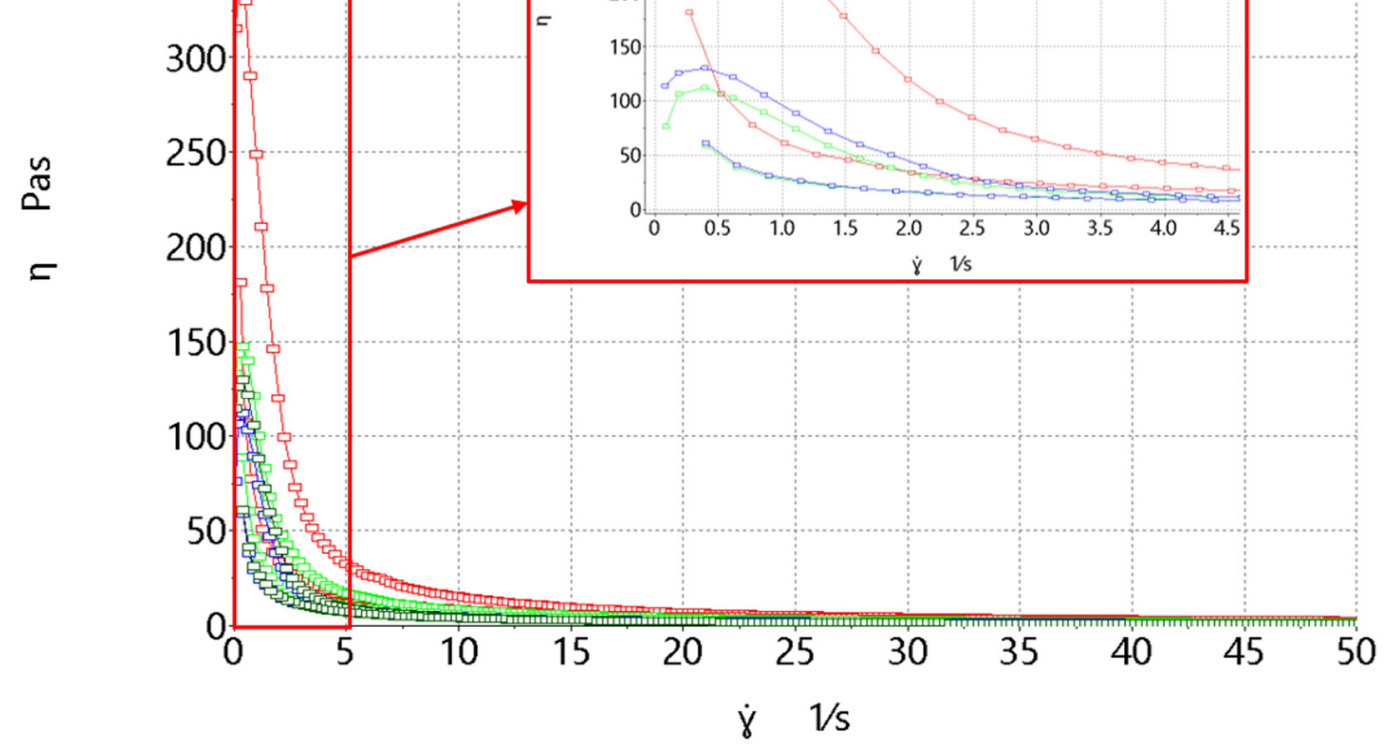

Figure 5. Viscosity and thixotropy of hot trub precipitated from 100\% Pilsner malt boiled for 60 min and collected from the industrial brewery at $15^{\circ} \mathrm{C}, 40^{\circ} \mathrm{C}, 60^{\circ} \mathrm{C}$, and $80^{\circ} \mathrm{C}$.

For industrial sediment, the highest maximum viscosity value was obtained at $15{ }^{\circ} \mathrm{C}$ (357.3 Pa.s) and the lowest at $60^{\circ} \mathrm{C}$ (111.9 Pa.s.) After heating to $80^{\circ} \mathrm{C}, \eta_{\max }$ of $129.8 \mathrm{~Pa} \cdot \mathrm{s}$ was observed. Such an increase in viscosity can be explained by the swelling of sediment conglomerates; however, no such behavior was observed in laboratory sediments. Their maximum viscosity value was significantly lower than that of semi-technical laboratory sediments.

Industrial sediment had the highest thixotropy value at $15^{\circ} \mathrm{C}(\Delta \mathrm{A}=2028 \mathrm{~Pa} / \mathrm{s})$. On the other hand, the lowest value $(\Delta \mathrm{A}=63.69 \mathrm{~Pa} / \mathrm{s})$ was recorded at $60{ }^{\circ} \mathrm{C}$. When heated to $80^{\circ} \mathrm{C}$, the hysteresis loop area value was $260.6 \mathrm{~Pa} / \mathrm{s}$. The equilibrium viscosity values decreased with increasing temperature: at $15^{\circ} \mathrm{C}, \eta_{\mathrm{eq}}=2.86 \mathrm{~Pa} \cdot \mathrm{s}$; at $60^{\circ} \mathrm{C}, \eta_{\mathrm{eq}}=1.37 \mathrm{~Pa} \cdot \mathrm{s}$; and at $80{ }^{\circ} \mathrm{C}, \eta_{\text {eq }}=1.16 \mathrm{~Pa} \cdot \mathrm{s}$.

Figure 6 shows charts of viscosity changes in the form of hysteresis loops from hops immersed in water at different temperatures. 


\begin{tabular}{|l|}
\hline$Z w_{-} 15^{\circ} \mathrm{C}$ \\
$-\eta=f(\dot{y})$ \\
$G w_{-} 15^{\circ} \mathrm{C}$ \\
$\eta=f(\dot{y})$ \\
\hline
\end{tabular}

a)

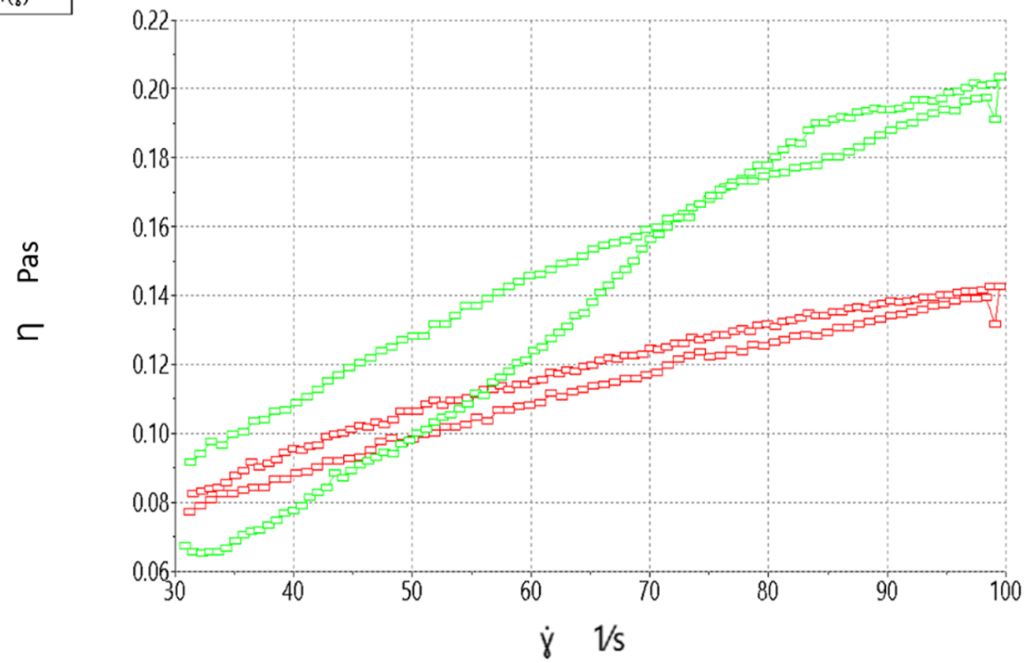

\begin{tabular}{|l|}
\hline$Z w \_60^{\circ} \mathrm{C}$ \\
$-\square=f(\dot{y})$ \\
$G w_{-} 60^{\circ} \mathrm{C}$ \\
$-\eta=f(\dot{y})$
\end{tabular}

b)

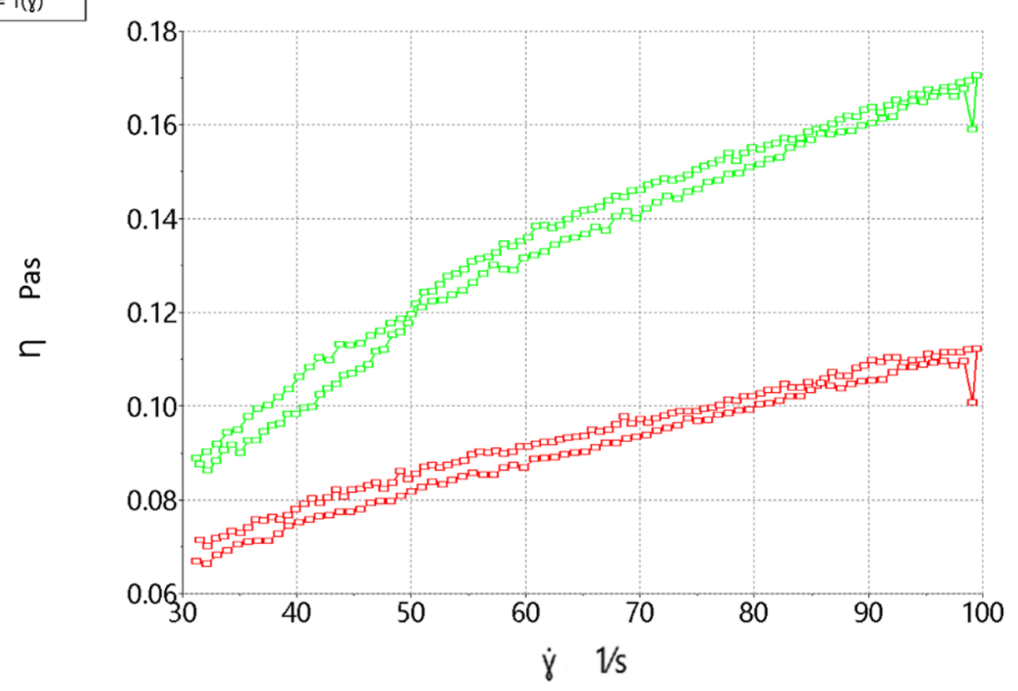

$Z w \_80^{\circ} \mathrm{C}$
$-\infty-\eta=f(y)$
$G w_{-} 80^{\circ} \mathrm{C}$

$G w_{-} 80^{\circ} \mathrm{C}$
$\eta=f(\dot{y})$

c)

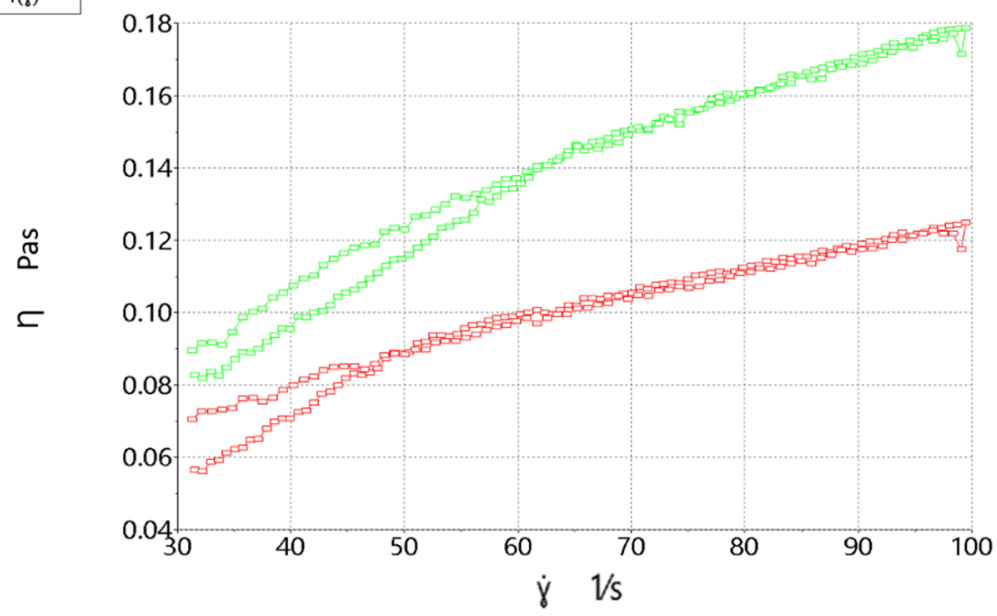

Figure 6. Viscosity and thixotropy loop of hops immersed in water, depending on the experimental variant, at (a) $15^{\circ} \mathrm{C}$, (b) $60^{\circ} \mathrm{C}$, and (c) $80{ }^{\circ} \mathrm{C}$. 
The highest viscosity at all temperatures was obtained for hops immersed in water at $100{ }^{\circ} \mathrm{C}(\mathrm{Gw})$. This was due to the greater swelling of hop particles. The increase in the suspension viscosity with increasing shear rate resulted from mixing. It was therefore not a typical shear thickening. Hence, the decrease in viscosity on the return curve was a result of the hop particle sedimentation. The viscosity value remained at a similar level (0.09 Pa.s) regardless of the material heating temperature.

When tested at $15^{\circ} \mathrm{C}$, the highest thixotropy $(\triangle \mathrm{A}=28.43 \mathrm{~Pa} / \mathrm{s})$ was discovered for hops immersed in water at $21^{\circ} \mathrm{C}(\mathrm{Zw})$. The lowest thixotropy $(\Delta \mathrm{A}=14.08 \mathrm{~Pa} / \mathrm{s})$ was found in hops immersed in water at $100^{\circ} \mathrm{C}(\mathrm{Gw})$.

The tests at $60{ }^{\circ} \mathrm{C}$ and at $15^{\circ} \mathrm{C}$ revealed the highest thixotropy $(\Delta \mathrm{A}=16.62 \mathrm{~Pa} / \mathrm{s})$ in hops immersed in water at $21^{\circ} \mathrm{C}(\mathrm{Zw})$. The lowest thixotropy $(\Delta \mathrm{A}=13.13 \mathrm{~Pa} / \mathrm{s})$ was found in hops immersed in water at $100{ }^{\circ} \mathrm{C}(\mathrm{Gw})$.

Hops can be added via pumps, and thus the viscosity is important. When tested at $80{ }^{\circ} \mathrm{C}$, the highest thixotropy $(\Delta \mathrm{A}=5.94 \mathrm{~Pa} / \mathrm{s})$ was found in hops immersed in water at $21{ }^{\circ} \mathrm{C}(\mathrm{Zw})$. The lowest thixotropy $(\Delta \mathrm{A}=0.1761 \mathrm{~Pa} / \mathrm{s})$ was found in hops immersed in water at $100{ }^{\circ} \mathrm{C}(\mathrm{Gw})$. Small hysteresis areas suggest that there was no destruction of the hop particle structure. The suspension created by immersion in cold water was more stable. The least stable suspension was obtained at $15^{\circ} \mathrm{C}$ for hops immersed in hot water.

Sewage sludges are non-Newtonian fluids [53]. Studies suggested that hot trub could also be composted and processed into fertilizer or used as a source of bioactive compounds [54]. Rheology is used to assess the quality of sewage sludge. Other authors studied the rheology of mixed primary and secondary miscellaneous pre-industrial sludge and how it depends on the solid content and temperature [55]. The rheological properties depend on the structure and surface characteristics of aggregates [56,57].

Cao et al. (2016) studied sewage sludge for $4,7,8,9$, and $10 \%$ total solids at $20{ }^{\circ} \mathrm{C}$, $35{ }^{\circ} \mathrm{C}$, and $55^{\circ} \mathrm{C}$. The apparent viscosity for these variants decreased noticeably at the beginning of shearing, and then tended to a relatively constant value. A similar tendency was noted for hot trub. Viscosity values ranged from $412.7 \mathrm{mPa} \cdot \mathrm{s}$ for $10 \%$ TS (Total Solids) at $20^{\circ} \mathrm{C}$ to $6.75 \mathrm{mPa} \cdot \mathrm{s}$ for $4 \%$ TS at $55^{\circ} \mathrm{C}$ [58]. Liu et al. (2012) studied rheological properties of slurry fuel prepared using municipal wastewater sludge and coal. Although the concentration was much higher than that of hot trub, the viscosity values ranged from 2750 to $1000 \mathrm{mPa} \cdot \mathrm{s}$ [59]. There are no waste products that have similar viscosity values to those of hot trub, which makes this study an innovation. On the other hand, shear thinning is a common property.

\section{Conclusions}

1. The study allowed us to conclude the following: Hot trub is a non-Newtonian thixotropic viscous fluid characterized by maximum viscosity, equilibrium viscosity, and a hysteresis loop area.

2. The viscosity of industrial sediment was significantly lower than that of semi-technical laboratory sediment. For manufacturers of pumps used in the brewing industry, the most convenient material is that of the lowest viscosity (longer boiling precipitated sediment). For hot trub that deposits in the central zone of the tank bottom, it would be better to have higher viscosity. This rheological feature also has great advantages when composting this industrial waste. Low viscosity hot trub can be removed at lower velocities, which makes its cleaning and transport easier and cheaper.

3. Puławski hops had the highest protein and dry matter contents; therefore, it was the best to study hot trub characteristics. Mixed with water at increasing shear rate, it created a uniform suspension. Hop sediments do not contain microbial contaminants and therefore remain fully sterile.

4. The mass of precipitated hot trub depends more on the share of cereal raw materials in the batch, and less on the type of hops.

5. The shorter the boiling of wort with hops (regardless of the raw material input), the lower the share of protein and dry matter in precipitated hot trub is. 
6. The use of hot water causes greater swelling of hop particles. However, hops immersed in cold water create a more stable suspension.

Author Contributions: Conceptualization, M.S.; methodology, K.W.-K.; validation, M.S.; formal analysis, M.S.; investigation, M.S.; resources, M.S.; data curation, M.S.; writing—original draft preparation, M.S.; writing-review and editing, M.Z. and K.W.-K.; visualization, K.W.-K.; supervision, M.Z.; funding acquisition, M.Z. All authors have read and agreed to the published version of the manuscript.

Funding: This study was supported by the National Centre for Research and Development, Poland (Grant No. LIDER/ 46/0185/L-9/17/NCBR/2018).

Data Availability Statement: Data are available from the authors.

Conflicts of Interest: The authors declare no conflict of interest.

\section{References}

1. Krishna, R.S.; Mishra, J.; Meher, S.; Das, S.K.; Mustakim, S.M.; Singh, S.K. Industrial solid waste management through sustainable green technology: Case study insights from steel and mining industry in Keonjahr, India. Mater. Today 2020, 33, 5243-5249. [CrossRef]

2. Perry, M.; De Villiers, G. Modelling the consumption of water and other utilities. Brauwelt Int. 2003, 5, $286-291$.

3. Sterczyńska, M.; Stachnik, M. Technical and technological aspects of clarification of beer wort. Pol. J. Food Eng. $2017,4,24-27$.

4. Podskoczy, A. Beer reigns among holiday drinks, National Social-Political and Economic-Legal Journal Rzeczpospolita. Renew. Sust. Energ. Rev. 2016, 76, 1134-1152. [CrossRef]

5. Sterczyńska, M.; Stachnik, M.; Poreda, A.; Jakubowski, M. Hot trub—by-product of production of clarified beer wort. Pol. J. Food Eng. 2018, 2, 36-41.

6. Knirsch, M.; Penschke, A.; Meyer-Pittroff, R. Disposal situation for brewery waste in Germany e results of a survey. Brauwelt Int. 1999, 6, 477-481.

7. Fillaudeau, L.; Blanpain-Avet, P.; Daufin, G. Water, wastewater and waste management in brewing industries. J. Clean. Prod. 2006, 14, 463-471. [CrossRef]

8. Kerby, C.; Vriesekoop, F. An overview of the utilisation of brewery by-products as generated by British craft breweries. Beverages 2017, 3, 24. [CrossRef]

9. $\quad$ van der Merwe, A.I.; Friend, J.F.C. Water management at a malted barley brewery. Water SA 2002, 28, 313-318. [CrossRef]

10. Piepiórka-Stepuk, J.; Diakun, J.; Mierzejewska, S. Poly-optimisation of cleaning conditions for pipe systems and plate heat exchangers contaminated with hot milk using the Cleaning in Place method. J. Clean. Prod. 2016, 112, 946-954. [CrossRef]

11. Piepiórka-Stepuk, J. Analysis of physical impurities in regenerated solutions used in cleaning brewing systems. J. Inst. Breww. 2018. [CrossRef]

12. Mishra, P.C.; Mukherjee, S.; Nayak, S.K.; Panda, A. A brief review on viscosity of nanofluids. Int. Nano Lett. 2014, 4, 109-120. [CrossRef]

13. Kumar, P.; Pandey, K.M. Effect on heat transfer characteristics of nanofluids flowing under laminar and turbulent flow regime. IOP Conf. Ser. Mater. Sci. Eng. 2017, 225, 012168. [CrossRef]

14. Murshed, S.M.S.; Estellé, P. A state of the art review on viscosity of nanofluids. Renew. Sustain. Energy Rev. 2017, 76, 1134-1152. [CrossRef]

15. Maia, A. Room temperature ionic liquids: A "green" alternative to conventional organic solvents? Mini-Rev. Org. Chem. 2011, 8, 178-185. [CrossRef]

16. Dealy, J.M.; Wang, J. Melt Rheology and its Applications in the Plastics Industry, 2nd raed. Springer, Dordrecht, the Netherlands, experimental research on the flow inside a whirlpool separator. J. Food Eng. 2013, 133, 9-15.

17. Piepiórka-Stepuk, J.; Mierzejewska, M.; Sterczyńska, M.; Jakubowski, M.; Marczuk, A.; Andrejko, D.; Sobczak, P. Analysis and modelling of the regeneration process of chemical solutions after brewing equipment cleaning in a Cleaning in Place system based on changes in turbidity. J. Clean. Prod. 2019, 237, 117745. [CrossRef]

18. Oladokun, O.; James, S.; Cowley, T.; Smart, K.; Hort, J.; Cook, D. Dry-hopping: The effects of temperature and hop variety on the bittering profiles and properties of resultant beers. Brew. Sci. 2017, 70, 187-196.

19. Pal, J.; Piotrowska, A.; Adamiak, J.; Czerwińska-Ledwig, O. Beer and brewing raw materials in cosmetology as well as beer baths as a treatment form. Adv. Fhytotherapy 2019, 20, 145-153.

20. Kunze, W. Technology Brewing \& Malting, 4th ed.; VLB Berlin: Berlin, Germany, 2014.

21. O'Rourke, T. Back to Basics 10-Wort Boiling (Part 2). Brew. Guard. 1999, 128, 38-41.

22. Lentini, A.; Takis, S.; Hawthorne, D.B.; Kavanagh, T.E. The influence of trub on fermentation and flavour development. Proceedings of the 23rd Convention Institute of Brewing (Asia Pacijk Section), Sydney. Inst. Brew. Aust. New 1994, 23, 89-95.

23. Kühbeck, F.; Schütz, M.; Thiele, F.; Krottenthaler, M.; Back, W. Influence of Lauter Turbidity and Hot Trub on Wort Composition, Fermentation, and Beer Quality. Am. Soc. Brew. Chem. 2006, 64, 16-28. [CrossRef] 
24. Bamforth, C.W. Beer: Tap into the Art and Science of Brewing, 2nd ed.; Oxford University Press: Oxford, UK, 2003; ISBN 0-19-515479-7.

25. Lewis, M.J.; Bamforth, C.W. Essays in Brewing Science; Springer Science+Business Media, LLC Springer Nature Switzerland AG.: Cham, Switzerland, 2006; Volume 13, ISBN 978-0387-33011-2.

26. Priest, F.G.; Stewart, G.G. Handbook of Brewing, 2nd ed.; Taylor \& Francis Group, LLC Registered in England \& Wales No. 3099067: Boca Raton, FL, USA, 2006; Volume 13, ISBN 978-0-8247-2657-7.

27. Jakubowski, M.; Antonowicz, A.; Janowicz, M.; Sterczyńska, M.; Piepiórka-Stepuk, J.; Poreda, A. An assessment of the potential of Shadow Sizing analysis and Particle Image Velocimetry (PIV) to characterise hot trub morphology. J. Food Eng. 2016, 173, 34-41. [CrossRef]

28. Kühbeck, F.; Müller, M.; Back, W.; Kurz, T.; Krottenthaler, M. Effect of hot trub and particle addition on fermentation performance of Saccharomyces cerevisiae. Enzym. Microb. Technol. 2007, 41, 711-720. [CrossRef]

29. Severa, L.; Havlíček, M.; Buchar, J.; Křivánek, I. On the Selected Rheological Parameters of Edible Vegetable Oils. Acta Univ. Agric. Silvic. Mendel. Brun. 2006, 54, 83-94. [CrossRef]

30. Piazza, P.; Gigli, J.; Bulbarello, A. Interfacial rheology study of espresso coffee foam structure and properties. J. Food Eng. 2008, 84, 420-429. [CrossRef]

31. Michael, J.; Sargent, B.; Hallmark, B. Investigating the shear rheology of molten instant coffee at elevated pressures using the Cambridge multipass rheometer. Food Bioprod. Process. 2019, 115, 17-29. [CrossRef]

32. Jóźwiak, B.; Boncel, S. Rheology of ionanofluids. J. Mol. Liq. 2020, 302, 112568. [CrossRef]

33. Jakubowski, M.; Diakun, J. Simulation investigations of the effects of whirlpool dimensional ratios on the state of secondary whirls. J. Food Eng. 2007, 83, 106-110. [CrossRef]

34. Jakubowski, M.; Sterczyńska, M. Analysis of PIV measurements of liquid flow velocity at the bottom of a whirlpool tank filled on both sides. Chem. Eng. Appar. 2013, 52, 185-186. (In Polish)

35. Stachnik, M.; Jakubowski, M. Multiphase model of flow and separation phases in whirlpool: Advanced simulation and phenomena visualization approach. J. Food Eng. 2020, 274, 109846. [CrossRef]

36. Fărcaş, A.C.; Socaci, S.A.; Mudura, E.; Dulf, F.V.; Vodnar, D.C.; Tofană, M.; Salanță, L.C. Exploitation of Brewing Industry Wastes to Produce Functional Ingredients. Brew. Technol. 2017, 137-156. [CrossRef]

37. Bedini, S.; Flamini, G.; Girardi, J.; Cosci, F.; Conti, B. Not just for beer: Evaluation of spent hops (Humulus lupulus L.) as a source of eco-friendly repellents for insect pests of stored foods. J. Pest Sci. 2015, 88, 583-592. [CrossRef]

38. Zanoli, P.; Zavatti, M. Pharmacognostic and pharmacological profile of Humulus lupulus L. J. Ethnopharmacol. 2008, 116, 383-396. [CrossRef] [PubMed]

39. Kanagachandran, K.; Jayaratne, R. Utilization potenctial od brewery waste water sediment as an organic fertilizer. J. Inst. Brew. 2006, 112, 92-96. [CrossRef]

40. Kopeć, M.; Mierzwa-Hersztek, M.; Gondek, K.; Wolny-Koładka, K.; Zdaniewicz, M.; Jarosz, R. Biological activity of composts obtained from hop waste generated during the brewing. Biomass Conv. Bioref. 2020a. [CrossRef]

41. Kopeć, M.; Mierzwa-Hersztek, M.; Gondek, K.; Wolny-Koładka, K.; Zdaniewicz, M. The application potential of hop sediments from beer production for composting. Saudi J. Biol. Sci. 2020, in press.

42. Wolny-Koładka, K.; Mateusz, M.; Zdaniewicz, M. Energy and microbiological evaluation of the effects of adding bulking agents on biodrying of brewery hot trub. Food Bioprod. Process. 2021, in press.

43. EBC Method 4.6. Hot Water Extract of Malt: Constant Temperature Mash. 1997. European Brewery Convention. Available online: https: / / brewup.eu/ (accessed on 15 May 2020).

44. Wolny-Koładka, K.; Żukowski, W. Mixed Municipal Solid Waste Hygienisation for Refuse-Derived Fuel Production by Ozonation in the Novel Configuration Using Fluidized Bed and Horizontal Reactor. Waste Biomass Valor 2019, 10, 575-583. [CrossRef]

45. Abram, V.; Čeh, B.; Vidmar, M.; Hercezi, M.; Lazíc, N.; Bucik, V.; Možina, S.S.; Košir, I.J.; Kač, M.; Demšar, L.; et al. A comparison of antioxidant and antimicrobial activity between hop leaves and hop cones. Ind. Crops Prod. 2015, 64, 124-134. [CrossRef]

46. Astray, G.; Gullón, P.; Gullón, B.; Munekata, P.E.S.; Lorenzo, J.M. Humulus lupulus L. as a Natural Source of Functional Biomolecules. Appl. Sci. 2020, 10, 5074. [CrossRef]

47. Chetrariu, A.; Dabija, A. Brewer's Spent Grains: Possibilities of Valorization, a Review. Appl. Sci. 2020, 10, 5619. [CrossRef]

48. Baca, E. Impact of water chemical composition on the production process and quality of beer. Ferment. Fruit Veg. Ind. 1999, 1, 35-38. (In Polish)

49. Zarnkow, M.; Kessler, M.; Burberg, F.; Back, W.; Arendt, E.K.; Kreisz, S. The use of response surface methodology to optimise malting conditions of proso millet (Panicum miliaceum L.) as a raw material for gluten-free foods. J. Inst. Brew. 2007, 113, 280-292. [CrossRef]

50. Narziß, L.; Back, W. Die Bierbrauerei: Band 2, Technologie der Würzebereitung, 8th ed.; Wiley-VHC: Weinheim, Germany, 2012.

51. Barnes, H.A. A Handbook of Elementary Rheology; Cambrian Printers: Aberystwyth, UK, 2000; SY23 3TN; ISBN 0-9538032-0-1.

52. Mezger, T.G. The Rheology Handbook: For Users of Rotational and Oscillatory Rheometers, 4th ed.; Vincentz Network: Hanover, Germany, 2014.

53. Dentel, S.K. Evaluation and Role of Rheological Properties in sediment Management. Water Sci. Technol. 1997, 36. [CrossRef]

54. Zawiślak, K.; Sobczak, P.; Kraszkiewicz, A.; Niedziółka, I.; Parafiniuk, S.; Kuna-Broniowska, I.; Tanaś, W.; Żukiewicz-Sobczak, W.; Obidziński, S. The use of lignocellulosic waste in the production of pellets for energy purposes. Renew. Energy 2020, 145, 997-1003. [CrossRef] 
55. Baroutian, S.; Eshtiaghi, N.; Gapes, D.J. Rheology of A Primary and Secondary Sewage Sludge Mixture: Dependency on Temperature and Solid Concentration. Bioresour. Technol. 2013, 140, 227-233. [CrossRef]

56. Behn, V.C. Experimental Determination Of sediment-Flow Parameters. J. Sanit. Eng. Div. 1962, 88, 39-54.

57. Lotito, V.; Spinosa, L.; Mininni, G.; Antonacci, R. The Rheology of Sewage sediment at Different Steps of Treatment. Water Sci. Technol. 1997, 36. [CrossRef]

58. Cao, X.; Jiang, Z.; Cui, W.; Wang, Y.; Yang, P. Rheological Properties of Municipal Sewage sediment: Dependency on Solid Concentration and Temperature. Procedia Environ. Sci. 2016, 31, 113-121. [CrossRef]

59. Liu, J.; Wang, R.; Gao, F.; Zhou, J.; Cen, K. Rheology and thixotropic properties of slurry fuel prepared using municipal wastewater sediment and coal. Chem. Eng. Sci. 2012, 76, 1-8. [CrossRef] 